\title{
Involvement of EGFR in the response of squamous cell carcinoma of the head and neck cell lines to gefitinib
}

\author{
TAKAHIDE TAGUCHI ${ }^{1}$, MAMORU TSUKUDA ${ }^{1,2}$, YUKARI IMAGAWA-ISHIGURO ${ }^{2}$, \\ YASUMASA KATO ${ }^{3}$ and DAISUKE SANO ${ }^{2}$ \\ ${ }^{1}$ Department of Otorhinolaryngology and Head and Neck Surgery, Yokohama City University School of Medicine; \\ ${ }^{2}$ Department of Biology and Function in Head and Neck, Yokohama City University Graduate School of \\ Medicine, Yokohama 236-0004; ${ }^{3}$ Department of Biochemistry and Molecular Biology, \\ Kanagawa Dental College, Yokosuka 238-8580, Japan
}

Received June 4, 2007; Accepted September 25, 2007

\begin{abstract}
Epidermal growth factor receptor (EGFR) gene mutations are associated with the sensitivity of non-small cell lung carcinomas (NSCLCs) to gefitinib, but such findings have not been reported in squamous cell carcinomas of the head and heck (SCCHNs). Accordingly, we determined whether EGFR gene expression and mutations correlate with the in vitro efficacy of gefitinib in SCCHN cell lines. EGFR status was analyzed in 16 different SCCHN cell lines by polymerase chain reaction (PCR) and direct sequencing for activating mutations, by real-time quantitative RT-PCR, and by Western blot analysis for RNA and protein expression. Using direct sequencing of PCR products from exons 18-23 of 9 SCCHN cell lines, we found a heterozygous $E G F R$ mutation $\left(E G F R_{\mathrm{mut}}\right)$ with a $2607 \mathrm{G}$, A transition in exon 20 (G/A genotype). The 9 different cell lines that showed this mutation also showed higher sensitivity (lower $\mathrm{IC}_{50}$ values) to gefitinib than cell lines with wild-type $E G F R\left(E G F R_{\mathrm{wt}}\right.$ : $\mathrm{G} / \mathrm{G}$ genotype $(\mathrm{p}=0.016)$. EGFR protein levels correlated robustly $(\mathrm{r}=0.76)$ and significantly $(\mathrm{p}=0.0007)$ with $E G F R$ mRNA levels and with $\mathrm{IC}_{50}$ values for gefitinib $(\mathrm{r}=0.65$, $\mathrm{p}=0.0067) . E G F R$ mRNA correlated with $\mathrm{IC}_{50}$ values $(\mathrm{r}=0.67$, $\mathrm{p}=0.0046$ ). Our conclusion was that the heterozygous and synonymous transition of the EGFR gene and low EGFR expression levels of mRNA and protein in SCCHN may be reliable predictors of high sensitivity in SCCHN patients to gefitinib.
\end{abstract}

Correspondence to: Dr Takahide Taguchi, Department of Otorhinolaryngology and Head and Neck Surgery, Yokohama City University School of Medicine, 3-9 Fukuura, Kanazawa-ku, Yokohama 236-0004, Japan

E-mail: ttaguchi@yokohama-cu.ac.jp

Key words: epidermal growth factor receptor, head and neck cancer, gene mutation, sensitivity to gefitinib

\section{Introduction}

Epidermal growth factor receptor (EGFR) is a $170 \mathrm{kDa}$ transmembrane glycoprotein receptor which exhibits a tyrosine kinase activity that regulates cell growth. EGFR overexpression has been frequently observed in squamous cell carcinomas of the head and neck (SCCHNs) and is thought to be involved in carcinogenesis and metastasis. Moreover, EGFR overexpression correlates with tumor size, clinical stage and poor prognosis (1-4). EGFR signaling has been found to control not only cell growth, but also angiogenesis and DNA repair $(5,6)$, and has recently been assessed as a molecular target in the treatment of SCCHN.

Gefitinib (ZD1839, Iressa ${ }^{\circledR}$ ), a low-molecular-weight anilinoquinazoline, is an orally active agent that reversibly inhibits EGFR tyrosine kinase activity. It has an acceptable toxicity profile and promising clinical efficacy in SCCHN patients in Phase I and II trials (7-10). Gefitinib is expected to be efficacious in non-small cell lung carcinoma (NSCLC) patients with high levels of EGFR expression because EGFR is also overexpressed in a significant portion of NSCLCs $(11,12)$. However, results from clinical trials on the treatment of NSCLC with gefitinib have been varied and not statistically significant (13-15). A potential molecular mechanism underlying this variable clinical response is suggested by recent reports showing that kinase domain mutations of the EGFR gene in NSCLC tissues predict clinical responses to gefitinib $(16,17)$.

In the present study, we determined whether EGFR gene expression and mutations correlate with in vitro efficacy of gefitinib in SCCHN cells.

\section{Materials and methods}

Reagents. Gefitinib was a gift from Astra-Zeneca Pharmaceuticals (Macclesfield, UK). RPMI-1640 was purchased from Nissui (Tokyo, Japan). Enhanced chemiluminescence (ECL) assay kits were from Amersham Biosciences (Piscataway, NJ). Protein assay kits were from Bio-Rad (Richmond, CA). SepaGene DNA purification kits were from Sanko Junyaku (Tokyo, Japan). TetraColor One MTT [3-(4,5-Dimethylthiazol- 
2-yl)-2,5-diphenyltetrazolium bromide] assay kits were from the Seikagaku Corporation (Tokyo, Japan). Isogen RNA extraction kits were from Nippon Gene (Tokyo, Japan). TaKaRa RNA PCR Kits (AMV) Version 3.0 were from Takara Bio (Tokyo, Japan). TaqMan PCR Reagent Kits were from Applied Biosystems (Foster City, CA). RNase was from Becton-Dickinson (Franklin Lakes, NJ). The antibodies used were as follows: anti-EGFR (sc-03) polyclonal antibody (pAb) (1:1000) (Santa Cruz Biotechnology, Santa Cruz, CA); anti-phospho-EGFR (1H12) monoclonal antibody (mAb) (1:1000), anti-p44/42 mitogen-activated protein (MAP) kinase pAb (1:1000), anti-phospho-p44/42 MAP Kinase pAb (1:1000), anti-Stat3 (124H6) mAb (1:1000) and antiphospho-Stat3 (58E12) mAb (1:1000) (all from Cell Signaling Technology, Danvers, MA); anti-ß-actin (AC-15) mAb (1:10000) (Sigma Aldrich, St. Louis, MO); sheep antimouse IgG antibody (1:1000) and donkey anti-rabbit IgG antibody (1:1000) (GE Healthcare Bio-Sciences, Piscataway, NJ).

Cell lines and culture conditions. Sixteen different cell lines derived from human head and neck squamous cell carcinomas (SCCs) were used in the study. The origins of these cell lines were: oropharynx (YCU-M862, YCU-M911, KCC-M871), hypopharynx (YCU-H891), larynx (KCC-L871, YCU-L891), tongue (KCC-T871, KCC-TCM902, KCC-TCM903, YCUT891, KCC-TCM901, YCU-T892 and KCC-T873), oral floor (KCC-OR891) maxillary sinus (KCC-MS871, YCU-MS861) $(18,19)$. KB (human oral floor carcinoma cells) and A431 (human epidermoid cancer cells of the cervix) were purchased from the Riken Cell Bank (Tsukuba, Japan). All cell lines were maintained in RPMI-1640 media supplemented with $10 \%$ fetal bovine serum and incubated at $37^{\circ} \mathrm{C}$ in a humidified atmosphere of $5 \% \mathrm{CO}_{2} / 95 \%$ air.

Western blot analysis. Whole cell homogenates were prepared for Western blot analysis with RIPA buffer consisting of $50 \mathrm{mM}$ Tris- $\mathrm{HCl}$ ( $\mathrm{pH} 8.0$ ), $150 \mathrm{mM}$ sodium chloride, $1 \%$ NP-40, $0.5 \%$ sodium deoxycholate and $0.1 \%$ sodium dodecyl sulfate (SDS). Nineteen samples containing $10 \mu \mathrm{g}$ protein were mixed with an equal volume of SDS sample buffer consisting of $4 \%$ SDS, $125 \mathrm{mM}$ Tris- $\mathrm{HCl}(\mathrm{pH} \mathrm{6.8)}$ ) and $10 \%$ glycerol, and then separated by 7.5 or $10 \%$ SDS-poly-acrylamide gel electrophoresis with prior heating at $95^{\circ} \mathrm{C}$ for $5 \mathrm{~min}$. The separated proteins were transferred onto PVDF membranes (Millipore, Bedford, MA) in $25 \mathrm{mM}$ Tris, $192 \mathrm{mM}$ glycine and $20 \%$ methanol. The blotted membranes were then blocked with 5\% BSA in Tris-buffered saline (TBS) and incubated with the appropriate primary antibodies. Peroxidase-conjugated anti-mouse and anti-rabbit antibodies were used as secondary antibodies. The presence of peroxidase was revealed by an ECL assay kit. Immuno-reacted bands were visualized by exposure to X-ray film (Kodak X-Omat AR; Eastman Kodak Co., Rochester, NY) and quantified by densitometric analysis using NIH Image Software. Protein concentrations were determined by the Bradford method using a Bio-Rad protein assay kit. BSA was used as the standard.

Detection of EGFR mutations. Genomic DNA was extracted using a SepaGene kit. Exons 18-23 of the EGFR gene were
Table I. Primer sets for EGFR mutation analysis.

\begin{tabular}{l} 
Target exon \\
$\begin{array}{l}\text { Exon } 18 \text { Forward: TCCAAATGAGCTGGCAAGTG }\left(5^{\prime}, 3^{\prime}\right) \\
\text { Reverse: TCCCAAACACTCAGTGAAACAAA }\end{array}$ \\
Exon 19 Forward: GTGCATCGCTGGTAACATCC \\
Reverse: TGTGGAGATGAGCAGGGTCT \\
Exon 20 Forward: ATCGCATTCATGCGTCTTCA \\
Reverse: ATCCCCATGGCAAACTCTTG \\
Exon 21 Forward: GCTCAGAGCCTGGCATGAA \\
Reverse: CATCCTCCCCTGCATGTGT \\
Exon 22 Forward: TGGCTCGTCTGTGTGTGTCA \\
Reverse: CGAAAGAAAATACTTGCATGTCAGA \\
Exon 23 Forward: TGAAGCAAATTGCCCAAGAC \\
Reverse: TGACATTTCTCCAGGGATGC \\
\hline
\end{tabular}

Table II. Primer sets for RT-PCR.

\begin{tabular}{lll}
\hline Target gene & \multicolumn{1}{c}{ Sequence $\left(5^{\prime}, 3^{\prime}\right)$} \\
\hline EGFR & Forward: & TTCGATGATCAACTCACGGAAC \\
& Reverse: & GCCACCCATATGTACCATCGAT \\
EGFR & Forward: & FAM-TGCTGGATGATAGACGCAG \\
(TaqMan) & & ATAGTCGCC-TAMRA \\
& Reverse: & FAM-ACCACCACGGCCGAGCGG- \\
& & TAMRA \\
B-actin & Forward: & TGAGCGCGGCTACAGCTT \\
& Reverse: & TCCTTAATGTCACGCACGATTT \\
\hline
\end{tabular}

amplified by polymerase chain reaction (PCR) using the specific primer sets listed in Table I (16). The PCR products were further analyzed by direct nucleotide sequencing using ABI PRISM 3100 DNA Analyzer (Applied Biosystems) in order to detect mutations.

Growth inhibition assay. Cells were seeded in 96-well plates at $1 \times 10^{4}$ cells/well in $100 \mu \mathrm{l}$ of medium. Twenty-four $\mathrm{h}$ after seeding, cells were treated with various concentrations of gefitinib for $24 \mathrm{~h}$. The inhibition of cell growth was assessed using the MTT colorimetric assay. Relative growth inhibition rates for the vehicle control were calculated and $\mathrm{IC}_{50}$ values were determined as the drug concentrations associated with $50 \%$ survival of cells.

Real-time quantitative RT-PCR. Total-RNA was extracted using Isogen RNA extraction kits according to the manu- 


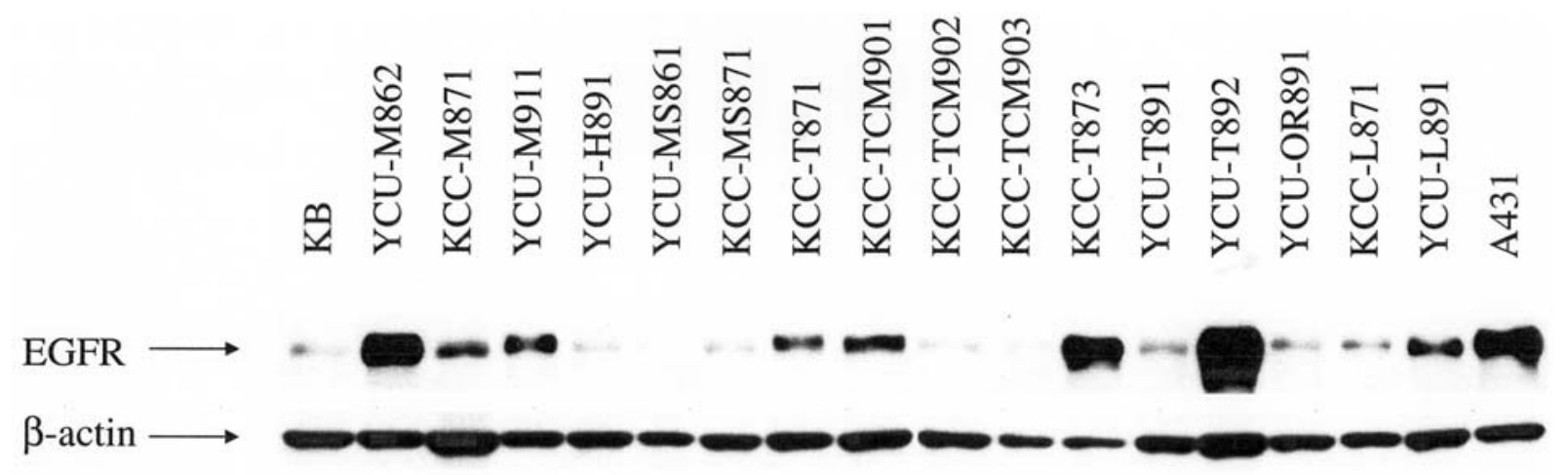

$\begin{array}{lllllllllllllllllllllllll}\text { EGFR/ } \beta \text {-actin } & 0.31 & 1.85 & 0.46 & 0.95 & 0.21 & 0.15 & 0.23 & 0.60 & 0.77 & 0.25 & 0.38 & 2.96 & 0.56 & 2.25 & 0.47 & 0.58 & 0.91 & 2.13\end{array}$

Figure 1. Expression of EGFR protein analyzed by Western blot analysis in 18 different cell lines. Expression levels of EGFR protein were determined by densitometry and relative expression levels by comparison with the expression levels of $\beta$-actin.

facturer's protocol. Total-RNA $(1 \mu \mathrm{g})$ was converted into cDNA using Takara RNA PCR Kits (AMV) Version 3.0. Real-time quantitative RT-PCR was carried out according to a fluorescence detection method using the TaqMan PCR Reagent kit or SYBG-based real-time PCR kit with specific primers, as shown in Table II. PCR was conducted using the following cycle parameters: $50^{\circ} \mathrm{C}$ for $2 \mathrm{~min}$ and $95^{\circ} \mathrm{C}$ for $10 \mathrm{~min}$ followed by 40 cycles at $95^{\circ} \mathrm{C}$ for $15 \mathrm{sec}$ and $60^{\circ} \mathrm{C}$ for $1 \mathrm{~min}$.

Data analysis of quantitative RT-PCR. The threshold cycle $\left(\mathrm{C}_{T}\right)$ value of a target gene was divided by the endogenous reference (B-actin) $\mathrm{C}_{T}$ value to correct for the input amount of cDNA. All corrected quantities were expressed as an n-fold difference relative to the gene expression levels of $\mathrm{KB}$ cells as the reference.

\section{Results}

Expression of EGFR protein and mRNA in SCCHN cell lines. We analyzed the expression of EGFR protein in 16 different SCCHN cell lines by Western blots (Fig. 1, Table III). Expression levels of EGFR protein in each cell line were determined by densitometry and by relative expression levels in comparison with the expression level of $\beta$-actin. EGFR protein was detectable in all cell lines tested; levels were higher in KCC-T873 and YCU-T892 than in the A431 (positive control) cells.

Using real-time quantitative RT-PCR, we analyzed steady state levels of EGFR mRNA in 16 different SCCHN cell lines (Table III). EGFR mRNA was detected in all the cell lines tested. The steady state level of EGFR mRNA was highest in KCC-T873 cells and lowest in KCC-M871 cells, with the difference being $>100$-fold.

Comparison of $I C_{50}$ values of gefitinib with EGFR expression and mutation. The drug concentrations, or $\mathrm{IC}_{50}$ values, used in each cell line and resulting in a $50 \%$ inhibition of cell growth are shown in Table III. KCC-MS871, KCC-TCM901 and KCC-T871 were the most sensitive to gefitinib, with $\mathrm{IC}_{50}$ values of $41.6,43.9$ and $44.4 \mu \mathrm{M}$, respectively.
Table III. Summary of EGFR expression and $\mathrm{IC}_{50}$ value for gefitinib.

\begin{tabular}{lccc}
\hline Cell line & $\begin{array}{c}\text { EGFR } \\
\text { protein }\end{array}$ & $\begin{array}{r}\text { EGFR } \\
\text { mRNA }\end{array}$ & $\begin{array}{c}\mathrm{IC}_{50} \text { value } \\
(\mu \mathrm{M})\end{array}$ \\
\hline YCU-OR891 & 0.47 & 7.38 & 53.6 \\
KCC-T871 & 0.60 & 0.89 & 44.4 \\
KCC-T873 & 2.96 & 36.62 & 85.0 \\
KCC-TCM901 & 0.77 & 0.15 & 43.9 \\
KCC-TCM902 & 0.25 & 0.17 & 50.2 \\
KCC-TCM903 & 0.38 & 1.21 & 51.4 \\
YCU-T891 & 0.56 & 3.23 & 56.0 \\
YCU-T892 & 2.25 & 7.70 & 64.8 \\
YCU-MS861 & 0.15 & 0.17 & 66.3 \\
KCC-MS871 & 0.23 & 1.38 & 41.6 \\
YCU-M862 & 1.85 & 0.70 & 64.8 \\
KCC-M871 & 0.46 & 0.09 & 52.1 \\
YCU-M911 & 0.95 & 0.43 & 61.4 \\
YCU-H891 & 0.21 & 1.04 & 69.0 \\
KCC-L871 & 0.58 & 1.34 & 58.0 \\
YCU-L891 & 0.91 & 4.23 & 52.2 \\
\hline
\end{tabular}

Linear regression showed that, across cell lines, EGFR protein levels correlated robustly with EGFR mRNA levels $(\mathrm{r}=0.76, \mathrm{p}=0.0007$; Fig. $2 \mathrm{~A})$ and with $\mathrm{IC}_{50}$ values of gefitinib $(\mathrm{r}=0.65, \mathrm{p}=0.0067$; Fig. 2B). Steady state levels of $E G F R$ mRNA also correlated robustly with $\mathrm{IC}_{50}$ values of gefitinib $(\mathrm{r}=0.67, \mathrm{p}=0.0046$; Fig. 2C). Although we found duplex bands of EGFR protein in some cases (see Fig. 5), EGFR protein levels did not have a significant correlation with any other parameters, including $\mathrm{IC}_{50}$ values.

Through the direct sequencing of PCR products from exons 18-23 of 9 SCCHN cell lines, we found a heterozygous EGFR mutation with a $2607 \mathrm{G}$ A transition (EGFRmut) in exon 20. 
A

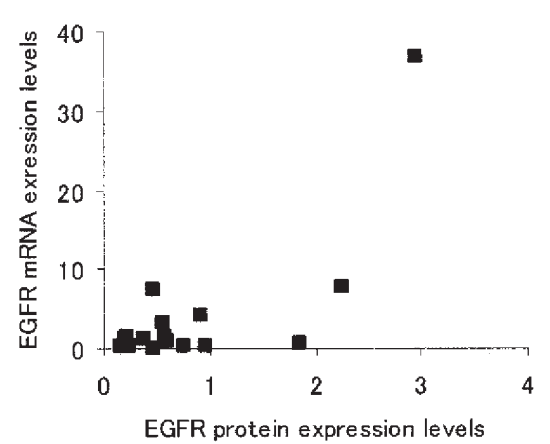

B

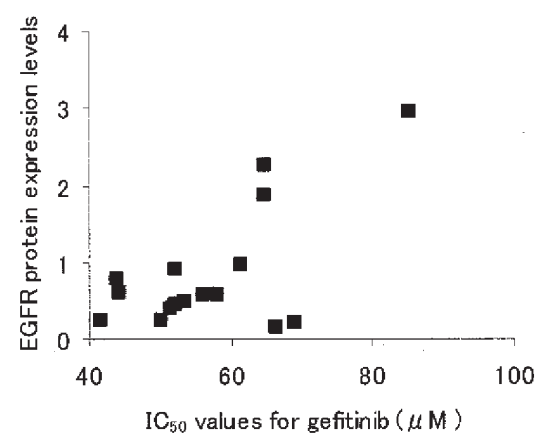

$\mathrm{C}$

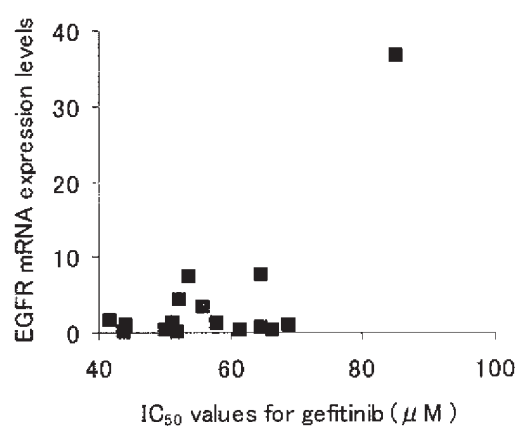

Figure 2. Response to gefitinib correlated to EGFR protein levels and EGFR mRNA levels. EGFR protein levels were determined by densitometric analysis of Western blot data as shown in Fig. 1. EGFR mRNA levels were quantified by real-time RT-PCR. (A) EGFR mRNA level vs. EGFR protein level (r=0.76, $\mathrm{p}=0.0007)$; (B) EGFR protein level vs. gefitinib $\mathrm{IC}_{50}(\mathrm{r}=0.65, \mathrm{p}=0.0067) ;(\mathrm{C})$ EGFR mRNA level vs. gefitinib $\mathrm{IC}_{50}(\mathrm{r}=0.67, \mathrm{p}=0.0046)$.

homo (GG)

YCU-M862

ACCTCCACCGTGCAGCTCATCACGCAG

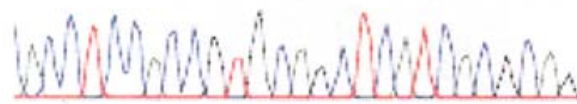

YCU-MS861

AC C TCACCG TG CAG C T CATCACG CA G
140

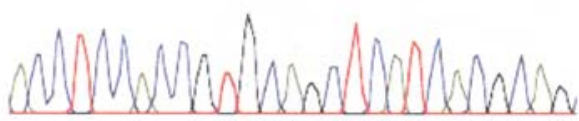

KCC-T873
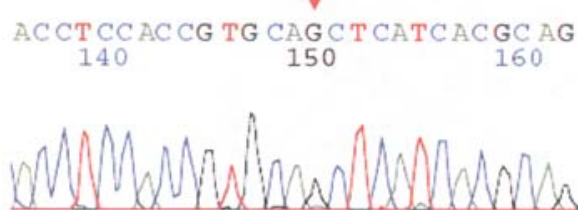

hetero (GA)

KCC-MS871 forward $\downarrow$

AC C T CCAC CG T G CAN CT CATCA CG CA G

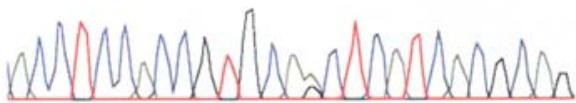

KCC-MS871 reverse $\downarrow$

$\begin{array}{ll}\text { C TGCG TG AT GAG NT GCACG G TG GAGG T' } \\ 70 & 180\end{array}$

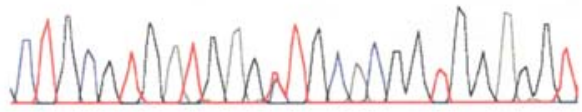

KCC-TCM902 forward $\downarrow$
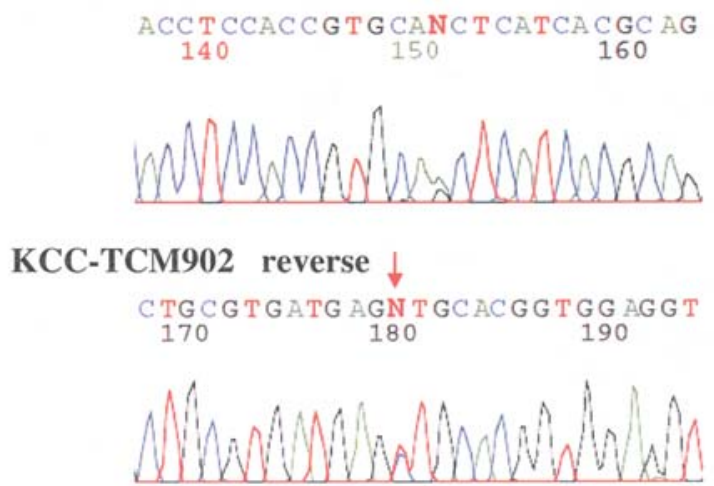

Figure 3. G/A genotype in EGFR gene. Genomic DNA was extracted and amplified with specific primers as shown in Table I. By direct sequencing of PCR products, single nucleotide polymorphisms (SNPs) (2607G A transition, G/A genotype) in exon 20 were found in 9 cell lines. The G/G genotype as EGFRwt was found in 7 cell lines. Representative results are shown: G/G genotype, YCU-M862, YCU-MS861 and KCC-T873; G/A genotype, KCC-MS871 and KCC-TCM902.

This transition was synonymous (Q787Q) and identified with a known single nucleotide polymorphism (SNP) (rs1050171 in the NCBI SNP database) (Fig. 3, Table IV). We then compared the frequencies of the EGFR gene genotype with the $\mathrm{IC}_{50}$ values of gefitinib (Fig. 4). The heterozygous EGFRmut (2607G ,A; G/A genotype) group, which was found in 9 different cell lines, showed a higher sensitivity (lower $\mathrm{IC}_{50}$ value) to gefitinib than did cell lines with wild-type $E G F R$ (EGFRwt; G/G genotype) ( $\mathrm{p}=0.016$; Fig. 4C). However, differences in EGFR protein or mRNA expression levels were not significant between the $\mathrm{G} / \mathrm{G}$ and $\mathrm{G} / \mathrm{A}$ genotypes (Fig. 4A and B). 
Table IV. Mutation in tyrosine kinase domain of EGFR.

\begin{tabular}{|c|c|}
\hline Cell line & Exon 20 (2607) \\
\hline YCU-OR891 & $\mathrm{G}, \mathrm{A}$ \\
\hline KCC-T871 & $\mathrm{G}, \mathrm{A}$ \\
\hline KCC-T873 & WT \\
\hline КСС-ТCM901 & $\mathrm{G}, \mathrm{A}$ \\
\hline КСС-ТCM902 & $\mathrm{G}, \mathrm{A}$ \\
\hline КСC-ТCM903 & $\mathrm{G}, \mathrm{A}$ \\
\hline YCU-T891 & $\mathrm{G}, \mathrm{A}$ \\
\hline YCU-T892 & WT \\
\hline YCU-MS861 & WT \\
\hline KCC-MS871 & $\mathrm{G}, \mathrm{A}$ \\
\hline YCU-M862 & WT \\
\hline KCC-M871 & WT \\
\hline YCU-M911 & WT \\
\hline YCU-H891 & $\mathrm{G}, \mathrm{A}$ \\
\hline KCC-L871 & WT \\
\hline YCU-L891 & $\mathrm{G}, \mathrm{A}$ \\
\hline
\end{tabular}

WT, wild-type.

Effects of gefitinib on signaling downstream of EGFR. We examined the effects of gefitinib on the phosphorylation of EGFR, STAT3 and p42/p44 MAP kinase in 5 representative cell lines carrying EGFRwt (YCU-M862, YCU-MS861 and KCC-T873 cells) and heterozygous EGFRmut (GA genotype) (KCC-MS871 and KCC-TCM901 cells) (Fig. 5). Regardless of genotype, EGFR was phosphorylated by EGF stimulation within 24 h. Its phosphorylation was significantly suppressed by gefitinib treatment in all 5 cell lines. STAT3 phosphorylation by EGF stimulation at $50 \mu \mathrm{g} / \mathrm{ml}$ was only seen in the GG genotype cell line, YCU-M862, and this activation was inhibited by gefitinib. In the other 4 cell lines, STAT3 was constitutively active. This activation was not altered by either EGF and/or gefitinib treatment. p44/42 MAP kinase was phosphorylated by the stimulation of EGF. This phosphorylation was decreased by gefitinib treatment in all 5 cell lines. However, in the G/A genotype cell line KCCTCM901, the inhibitory effect of gefitinib on MAP kinase phosphorylation was weak. As shown in Table III, the $\mathrm{IC}_{50}$ values of gefitinib in YCU-M862 cells (remarkable downregulation of STAT3 phosphorylation by gefitinib) and KCC-TCM901 cells (insensitive to the MAP kinasephosphorylation-inhibitory activity of gefitinib) were 66.3 and $43.9 \mu \mathrm{M}$, respectively. These data suggest that the inhibition of phosphorylated levels of p44/42 MAP kinase and STAT3 after gefitinib treatment are not predictors of a response to gefitinib.

\section{Discussion}

In earlier studies, the efficacy of gefitinib was thought to depend on EGFR expression levels in NSCLCs as compared to adjacent normal cells $(12,20)$. However, this concept has recently been negated in other clinical trials. The most recent study showed that EGFR protein levels did not differ between SCCs and adenocarcinomas in lung cancer and that there were no significant correlations between EGFR expression and gefitinib $\mathrm{IC}_{50}$ values (21). Moreover, the report showed that NSCLC cell lines with high copy numbers of the EGFR gene were more sensitive to gefitinib treatment, and suggested that high copy numbers of EGFR are a benefit in gefitinib treatment (21).

Unlike studies on cell lines from lung cancers, the present study showed an association between expression levels of
A

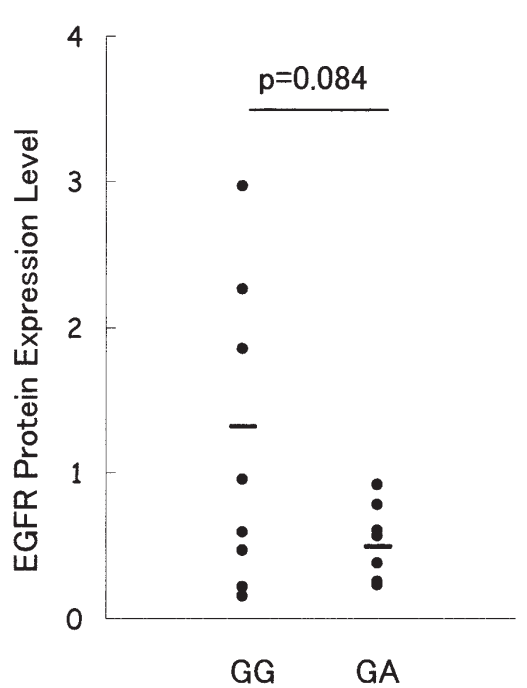

B

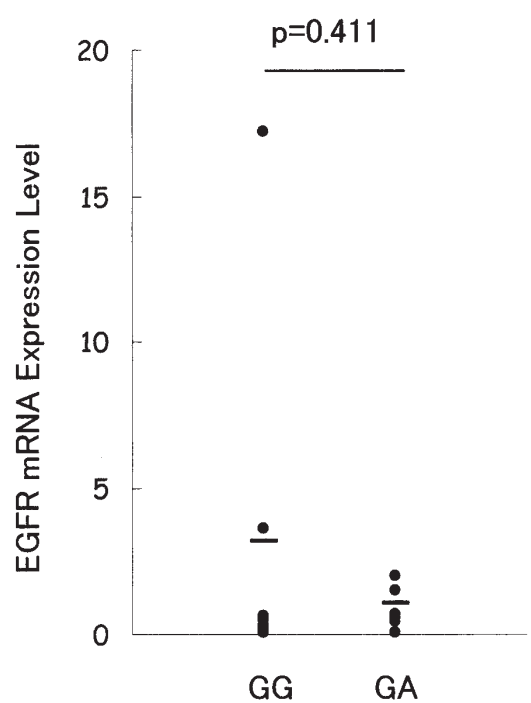

$\mathrm{C}$

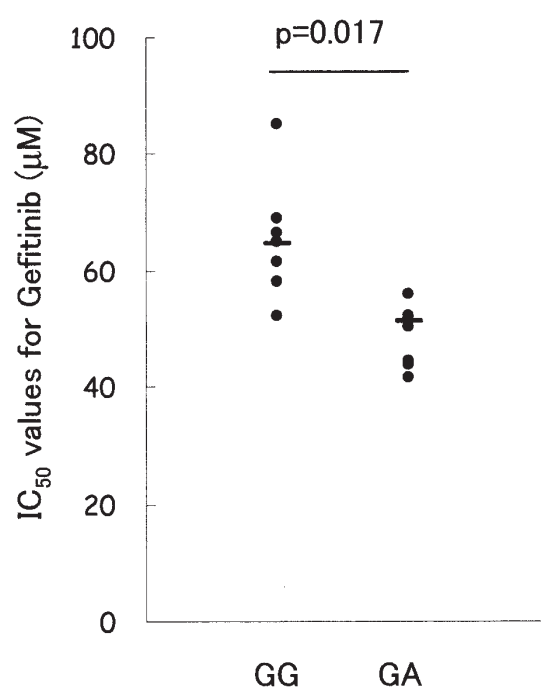

Figure 4. G/A genotype as an indicator of high response rate to gefitinib. G/G and G/A genotypes were compared in terms of (A) EGFR protein level, (B) EGFR mRNA level and (C) $\mathrm{IC}_{50}$ values of gefitinib. Cells with the $\mathrm{G} / \mathrm{A}$ genotype showed higher drug sensitivity (lower $\mathrm{IC}_{50}$ values) to gefitinib than did those with the G/G genotype (EGFRwt). Statistical analysis, paired Student's t-test. 


\section{YCU-M862}

$\begin{array}{ll}\text { ZD } 1839(10 \mu \mathrm{M}) & ---+++ \\ \text { EGF }(\mathrm{ng} / \mathrm{ml}) & -1050-105 \\ \text { pEGFR } & - \\ \text { EGFR } & \\ \text { pSTAT3 } & \\ \text { STAT3 } & \\ \text { pMAPK } & \\ \text { MAPK } & \\ \text { 及-actin } & \end{array}$

\section{YCU-MS861}

\begin{tabular}{|c|c|}
\hline ZD $1839(10 \mu \mathrm{M})$ & ---+++ \\
\hline $\mathrm{EGF}(\mathrm{ng} / \mathrm{ml})$ & $-1050-1050$ \\
\hline pEGFR & f \\
\hline EGFR & me日e \\
\hline pSTAT3 & 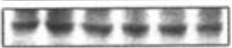 \\
\hline STAT3 & $-\infty-\infty-\infty$ \\
\hline pMAPK & 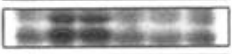 \\
\hline MAPK & 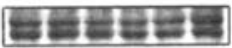 \\
\hline$\beta$-actin & $\sim \sim \sim \sim \sim n$ \\
\hline
\end{tabular}

\section{KCC-T873}

$\begin{array}{ll}\text { ZD } 1839(10 \mu \mathrm{M}) & ---+++ \\ \text { EGF }(\mathrm{ng} / \mathrm{ml}) & -1050-1050 \\ \text { pEGFR } & -00 \\ \text { EGFR } & \\ \text { pSTAT3 } & \\ \text { STAT3 } & \\ \text { pMAPK } & \\ \text { MAPK } & \\ \text { B-actin } & \end{array}$

\section{KCC-MS871}

$\mathrm{ZD} 1839(10 \mu \mathrm{M})---+++$ $-1050-1050$

pEGFR

EGFR

pSTAT3

STAT3

PMAPK

MAPK

$\beta$-actin

\section{KCC-TCM901}

$\begin{array}{ll}\text { ZD 1839 }(10 \mu \mathrm{M}) & --++++ \\ \text { EGF }(\mathrm{ng} / \mathrm{ml}) & -1050-1050 \\ \text { pEGFR } & \text { E } \\ \text { EGFR } & \\ \text { pSTAT3 } & \\ \text { STAT3 } & \\ \text { pMAPK } & \\ \text { MAPK } & \end{array}$

Figure 5. Effect of gefitinib on the downstream signaling of EGFR. The effects of gefitinib on the phosphorylation of EGFR, STAT3 and p42/p44 MAP kinase were examined in cell lines representative of EGFRwt (YCU-M862, YCU-MS861 and KCC-T873 cells) or heterozygous EGFRmut (GA genotype) (KCC-MS871 and KCC-TCM901 cells). EGFR was phosphorylated by EGF stimulation. Its phosphorylation was significantly suppressed by gefitinib treatment in all 5 cell lines. STAT3 phosphorylation by EGF stimulation at $50 \mu \mathrm{g} / \mathrm{ml}$ was only seen in the GG genotype cell line YCU-M862, and this activation was inhibited by gefitinib. The p44/42 MAP kinase was phosphorylated by stimulation with EGF. This phosphorylation was decreased by gefitinib treatment in all 5 cell lines. However, in the G/A genotype cell line KCC-TCM901, the inhibitory effect of gefitinib on MAP kinase phosphorylation was weak.

EGFR protein and gefitinib $\mathrm{IC}_{50}$ in cell lines from SCCHNs. However, we also showed that even SCCHN cell lines that are sensitive to gefitinib require higher concentrations (higher $\mathrm{IC}_{50}$ values) than those reported for NSCLC (22). This suggests that, in order to show clinical efficacy, the dose for patients with SCCHN might need to be higher than the approved dose (250 mg/day) for patients with NSCLC.

Several articles have revealed molecular mechanisms in which EGFR gene mutations are associated with altered sensitivity to gefitinib in NSCLCs $(16,23,24)$. Mutations of the $E G F R$ gene in the tyrosine kinase domain at exons 18-21 are one of the critical factors of gefitinib response in NSCLC (25). Of these mutations, $86 \%$ were found in 2 hotspot regions, exons 19 and 21, with the remaining $14 \%$ scattered throughout exons 18-21, whereas in SCCHNs it has been reported that EGFR mutations are predominant in exon $19(22,26)$. EGFR mutations in the tyrosine kinase domain were common in Asian patients (7.3\%) (26) and rare in Caucasian patients (1\%) (22). We observed an SNP in exon 20 of 9/16 SCCHN cell lines tested $(56.3 \%)$. This SNP, listed in the NCBI SNP database as rs1050171, is located in the EGFR tyrosine kinase domain. Due to a synonymous transition (Q787Q), it has been considered a silent mutation. The current frequencies of the genotype at this position are: European, A/A (37.5\%), A/G (45.8\%), G/G (16.7\%); Asian, A/A (4.2\%), A/G (20.8\%), $\mathrm{G} / \mathrm{G}(75.0 \%)$ (NCBI database, rs 1050171). The efficacy of gefitinib against SCCHN in Caucasians is not significantly different than it is in Asians, although this genotype has a higher incidence of occurence in Europe. The presence of this SNP (G/A genotype) is therefore limited. However, it may be a beneficial parameter in Asian patients with SCCHN since, in the present study, the heterozygous EGFRmut (G/A genotype) group showed higher sensitivity (lower $\mathrm{IC}_{50}$ values) to gefitinib than the EGFRwt (G/G genotype) group did.

Dominant mutations observed in NSCLCs were the deletion of 2-15 nucleotides between codon E740 and 753 in exon 19, e.g., delE747_E749 and delE746_A750, and a point mutation, L858R, in exon 21 (25). These mutations increase the tyrosine kinase inhibitory activity of gefitinib due to conformational changes at the ATP-binding site. However, they were rare in SCCHNs in both our study and those of others (26). Our data show a good correlation between synonymous mutations (Q787Q) and response to gefitinib. It is thought that synonymous mutation Q787Q may not be 'silent', but may in fact result in abnormal splicing. For example, in Marfan syndrome a synonymous amino acid substitution (Q508Q) of TGFBR2 (transforming growth factor- $\beta$ receptor 2 ) has been reported to occur because of abnormal splicing (27). The tau gene, whose encoded protein is associated with microtubule formation, has an $\mathrm{S} 305 \mathrm{~S}$ silent mutation which causes progressive supranuclear palsy pathology (28). 
In some of the SCCHN cell lines tested in the present study, we found duplexes in the anti-EGFR antibody-reactive band. However, this alteration was not strongly correlated with either the frequency of the synonymous mutation or with the response to gefitinib. Alternatively, a synonymous mutation may affect the half-life of EGFR mRNA or EGFR turnover. Further studies are needed to clarify the effects of Q787Q mutations on the production of abnormal splicing variants.

In conclusion, we found that high expression levels of EGFR mRNA and protein are associated with low sensitivity to gefitinib. Furthermore, cell lines with heterozygous and synonymous transitions of the EGFR gene (Q787Q, rs1050171 (NCBI SNP database) have a significantly higher sensitivity to gefitinib than do EGFRwt cell lines. Thus, our data suggest new advantages in molecular-targeting therapy using gefitinib for selected patients with SCCHN.

\section{References}

1. Eisbruch A, Blick M, Lee JS, Sacks PG and Gutterman J: Analysis of the epidermal growth factor receptor gene in fresh human head and neck tumors. Cancer Res 47: 3603-3605, 1987.

2. Santini J, Formento JL, Francoual M, Milano G, Schneider M, Dassonville O and Demard F: Characterization, quantification, and potential clinical value of the epidermal growth factor receptor in head and neck squamous cell carcinomas. Head Neck 13: 132-139, 1991.

3. Dassonville O, Formento JL, Francoual M, et al: Expression of epidermal growth factor receptor and survival in upper aerodigestive tract cancer. J Clin Oncol 11: 1873-1878, 1993.

4. Olayioye MA, Neve RM, Lane HA and Hynes NE: The ErbB signaling network: receptor heterodimerization in development and cancer. EMBO J 19: 3159-3167, 2000.

5. Wheeler RH, Spencer S, Buchsbaum D and Robert F: Monoclonal antibodies as potentiators of radiotherapy and chemotherapy in the management of head and neck cancer. Curr Opin Oncol 11: 187-190, 1999.

6. Schlessinger J: Cell signaling by receptor tyrosine kinases. Cell 103: 211-225, 2000.

7. Herbst RS, Maddox AM, Rothenberg ML, et al: Selective oral epidermal growth factor receptor tyrosine kinase inhibitor ZD1839 is generally well-tolerated and has activity in nonsmall-cell lung cancer and other solid tumors: results of a phase I trial. J Clin Oncol 20: 3815-3825, 2002.

8. Baselga J, Rischin D, Ranson M, et al: Phase I safety, pharmacokinetic, and pharmacodynamic trial of ZD1839, a selective oral epidermal growth factor receptor tyrosine kinase inhibitor, in patients with five selected solid tumor types. J Clin Oncol 20: 4292-4302, 2002.

9. Cohen EE, Rosen F, Stadler WM, Recant W, Stenson K, Huo D and Vokes EE: Phase II trial of ZD1839 in recurrent or metastatic squamous cell carcinoma of the head and neck. J Clin Oncol 21: 1980-1987, 2003.

10. Cohen EE, Kane MA, List MA, et al: Phase II trial of gefitinib $250 \mathrm{mg}$ daily in patients with recurrent and/or metastatic squamous cell carcinoma of the head and neck. Clin Cancer Res 11: 8418-8424, 2005.

11. Hunts J, Ueda M, Ozawa S, Abe O, Pastan I and Shimizu N: Hyperproduction and gene amplification of the epidermal growth factor receptor in squamous cell carcinomas. Jpn J Cancer Res 76: 663-666, 1985.
12. Rusch V, Baselga J, Cordon-Cardo C, et al: Differential expression of the epidermal growth factor receptor and its ligands in primary non-small cell lung cancers and adjacent benign lung. Cancer Res 53: 2379-2385, 1993.

13. Fukuoka M, Yano S, Giaccone G, et al: Multi-institutional randomized phase II trial of gefitinib for previously treated patients with advanced non-small-cell lung cancer (The IDEAL 1 Trial). J Clin Oncol 21: 2237-2246, 2003.

14. Kris MG, Natale RB, Herbst RS, et al: Efficacy of gefitinib, an inhibitor of the epidermal growth factor receptor tyrosine kinase, in symptomatic patients with non-small cell lung cancer: a randomized trial. JAMA 290: 2149-2158, 2003.

15. Janne PA, Gurubhagavatula S, Yeap BY, et al: Outcomes of patients with advanced non-small cell lung cancer treated with gefitinib (ZD1839, 'Iressa') on an expanded access study. Lung Cancer 44: 221-230, 2004.

16. Paez JG, Janne PA, Lee JC, et al: EGFR mutations in lung cancer: correlation with clinical response to gefitinib therapy. Science 304: 1497-1500, 2004.

17. Lynch TJ, Bell DW, Sordella R, et al: Activating mutations in the epidermal growth factor receptor underlying responsiveness of non-small-cell lung cancer to gefitinib. N Engl J Med 350: 2129-2139, 2004

18. Nishimura G, Yanoma S, Satake K, et al: An experimental model of tumor dormancy therapy for advanced head and neck carcinoma. Jpn J Cancer Res 91: 1199-1203, 2000.

19. Taguchi T, Kato Y, Baba Y, et al: Protein levels of p21, p27, cyclin $\mathrm{E}$ and Bax predict sensitivity to cisplatin and paclitaxel in head and neck squamous cell carcinomas. Oncol Rep 11: 421-426, 2004.

20. Ozanne B, Richards CS, Hendler F, Burns D and Gusterson B: Over-expression of the EGF receptor is a hallmark of squamous cell carcinomas. J Pathol 149: 9-14, 1986.

21. Helfrich BA, Raben D, Varella-Garcia M, et al: Antitumor activity of the epidermal growth factor receptor (EGFR) tyrosine kinase inhibitor gefitinib (ZD1839, Iressa) in non-small cell lung cancer cell lines correlates with gene copy number and EGFR mutations but not EGFR protein levels. Clin Cancer Res 12: 7117-7125, 2006

22. Loeffler-Ragg J, Witsch-Baumgartner M, Tzankov A, et al: Low incidence of mutations in EGFR kinase domain in Caucasian patients with head and neck squamous cell carcinoma. Eur J Cancer 42: 109-111, 2006.

23. Cappuzzo F, Magrini E, Ceresoli GL, et al: Akt phosphorylation and gefitinib efficacy in patients with advanced non-small-cell lung cancer. J Natl Cancer Inst 96: 1133-1141, 2004.

24. Sordella R, Bell DW, Haber DA and Settleman J: Gefitinibsensitizing EGFR mutations in lung cancer activate anti-apoptotic pathways. Science 305: 1163-1167, 2004.

25. Pao W and Miller VA: Epidermal growth factor receptor mutations, small-molecule kinase inhibitors, and non-small-cell lung cancer: current knowledge and future directions. J Clin Oncol 23: 2556-2568, 2005.

26. Lee JW, Soung YH, Kim SY, et al: Somatic mutations of EGFR gene in squamous cell carcinoma of the head and neck. Clin Cancer Res 11: 2879-2882, 2005.

27. Mizuguchi T, Collod-Beroud G, Akiyama T, et al: Heterozygous TGFBR2 mutations in Marfan syndrome. Nat Genet 36: 855-860, 2004.

28. Stanford PM, Halliday GM, Brooks WS, et al: Progressive supranuclear palsy pathology caused by a novel silent mutation in exon 10 of the tau gene: expansion of the disease phenotype caused by tau gene mutations. Brain 123 (Pt. 5): 880-893, 2000. 